\title{
Hazards associated with municipal waste storage. Vol. I
}

\author{
Anna Dmochowska ${ }^{1, *}$ \\ ${ }^{1}$ The Main School of Fire Service of Fire, Faculty Safety Engineering, 52/54 Slowackiego St., \\ 01-629 Warsaw, Poland
}

\begin{abstract}
Depositing municipal waste in a responsible and controlled manner in landfills allows their decomposition to stabilized material. However, there are many environmental risks during operation and stabilization after landfill closure. These include: dusts, odors, potential fires associated with the presence of landfill gas and it is microbiological hazards and leachates. The latter are also generated many years after closure and reclamation of the landfill. In the event of a leak trough the anti-filtration shutter, toxic compounds found in the leachates can migrate and contaminate to groundwater. The article presents the quantitative and qualitative analysis of leachates in the final operational period of the landfill and after its closure. In both cases, the chromatographic analysis was carried out using the same conditions, i.e. solvent, extraction time, chromatograph and conditions for chromatographic analysis of samples. Physical and chemical leachate examinations were performed on the basis of valid standards. Their results show that the waste deposit is subject to increasingly advanced biodegradation processes of organic compounds. The values of such indicators as $\mathrm{COD}$ and $\mathrm{BZT}_{5}$ are decreasing. However, they remain quite significant, which indicates the presence of hard-to decompose and newly compounds in the leachates.
\end{abstract}

\section{Introduction}

The main purpose in planning, selecting a location and arranging a storage site is to implement such safeguards to limit the potential negative environmental effects of its impact on the environment [1-4]. Unfortunately, for economic reasons, investors minimize related expenses [5-9]. They concern related works with the acquisition of suitable soils with a certain permeability, constituting a natural barrier to pollution, research on the level and directions of water migration, changes in aquifers, the possibility of technical improvement of soil insulation properties [10-15]. The currently closed Łubna landfill, located about $40 \mathrm{~km}$ from the center of Warsaw, was initially the only facility receiving unsorted municipal waste from the capital city [16-20].

The location of the landfill is shown in the Figure 1.

\footnotetext{
* Corresponding author: admochowska@sgsp.edu.pl
} 


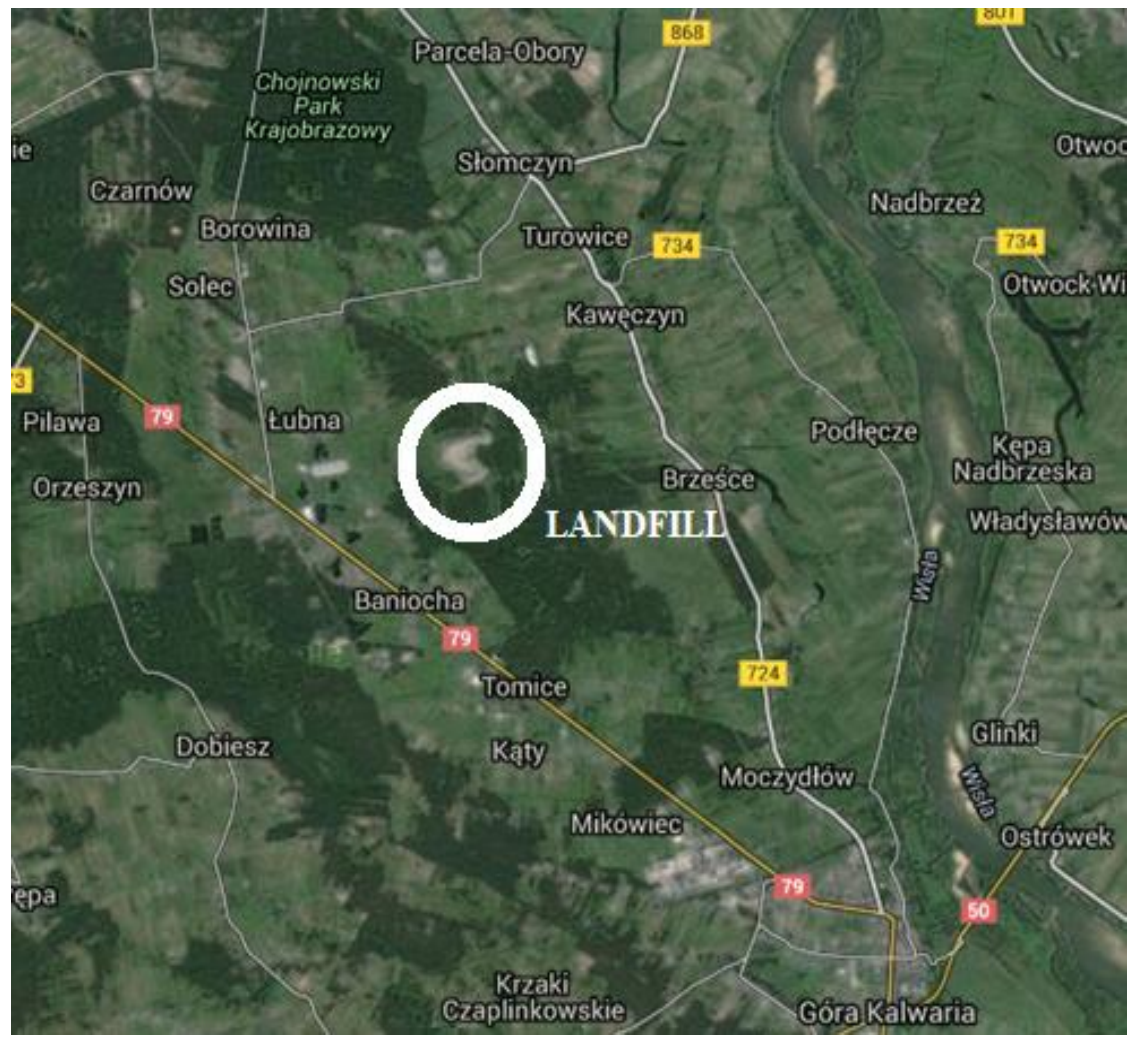

Fig. 1. Places located in the vicinity of the landfill.

The aim of the study was to conduct a comparative analysis of the results of physicalchemical and chromatographic tests of leachates carried out at the end of the operational period of the landfill - 2003-2007 with the results of the leachate tests collected after its closure - 2014 and 2015.

\section{Material and methods}

The Figure 2 shows the method of collecting of leachate from the well. 


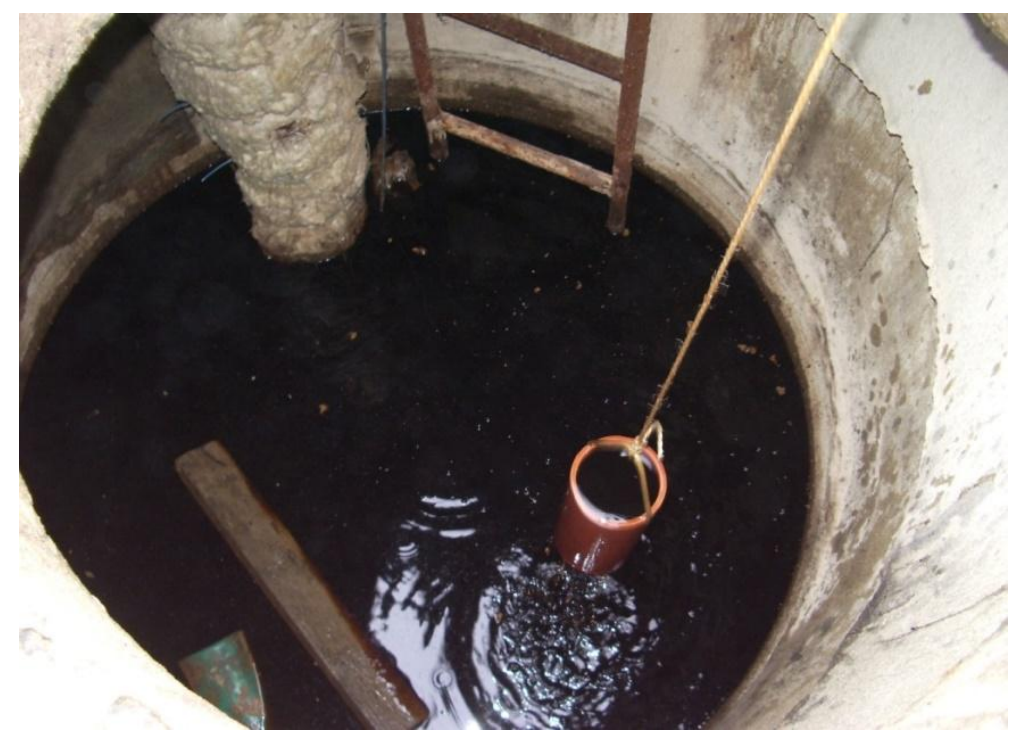

Fig. 2. Sampling method for leachate.

The research on Chemical Oxygen Demand (COD) was performed using the bichromate method according to PN-ISO 15705 and Biochemical Oxygen Demand $\left(\mathrm{BOD}_{5}\right)$ - using the Sapromat BSB digi from Selutec and the dilution method according to PN-EN 1899-1: 2000 [21-23]. Before the measurement, the remaining chlorine was removed from the sample with a stoichiometric amount of sodium sulfate [24-27]. The leachate samples for chromatographic tests were extracted with dichloromethane $\left(10 \mathrm{~cm}^{3}\right.$ dichloromethane $/ 200$ $\mathrm{cm}^{3}$ sample) by hand shaking for $5 \mathrm{~min}$ [28]. After extraction, the organic layer was separated and the samples were extracted again with dichloromethane $\left(10 \mathrm{~cm}^{3}\right.$ dichloromethane $/ 200 \mathrm{~cm}^{3}$ sample) [29-31]. Due to the formation of emulsions, the separation of the aqueous and organic phase was slow, centrifugation was carried out $(2,500 \times \mathrm{g}, 10 \mathrm{~min})$ to fully separate the phases [32-35]. The organic fraction was concentrated (ca. 6x) by evaporation of dichloromethane at ca. $37^{\circ} \mathrm{C}$ [36-40]. After concentration the samples were subjected to GC-MS analysis on a Shimadzu QP2010 apparatus [41-46]. The conditions of the chromatographic analysis are: column Phenomenex ZB-5MS, (30 m, $0.25 \mathrm{~mm}$ id, film thickness $0.25 \mathrm{~mm}$ ), dispenser temperature$280^{\circ} \mathrm{C}$, Detector temperature- $230^{\circ} \mathrm{C}$, Interface temperature- $280^{\circ} \mathrm{C}$, Program temperature$40^{\circ} \mathrm{C}$ for $1 \mathrm{~min}, 10^{\circ} \mathrm{C} / \mathrm{min}$ to $310^{\circ} \mathrm{C}, 310^{\circ} \mathrm{C}$ for $5 \mathrm{~min}$, Carrier gas - Helium, Dispensed volume - $1 \mathrm{ml}$, Delay of detector activation - $2.6 \mathrm{~min}$, Scan- 40-400 amu, Energy fragmentation-70 eV, Dosing - No division, sampling time $0.3 \mathrm{~min}$; gas pressure: $300 \mathrm{kPa}$ $/ 1 \mathrm{~min}$ (flow: $6.7 \mathrm{ml} / \mathrm{min}$ ), helium flow through the column $-1.2 \mathrm{ml} / \mathrm{min}$. [47-50].

\section{Results}

Obtained results of physical and chemical tests show that in the deposit of collected waste there are increasingly advanced processes of biodegradation of organic compounds which reflect the decreasing values of such indicators as COD and $\mathrm{BZT}_{5}$ in 2007 , respectively $3012 \mathrm{mg} / \mathrm{dm}^{3} \mathrm{O}_{2}$ and $891 \mathrm{mg} / \mathrm{dm}^{3} \mathrm{O}_{2}$ and in 2015 , respectively, $2330 \mathrm{mg} / \mathrm{dm}^{3} \mathrm{O}_{2}$ and 616 $\mathrm{mg} / \mathrm{dm}^{3} \mathrm{O}_{2}$. However, they remain quite significant which indicates the presence of hardly decomposable compounds in the leachate. This is proven by both the qualitative and quantitative chromatographic analysis.

Figure 3 shows the chromatogram of the concentrated extract from leachate (2015). 


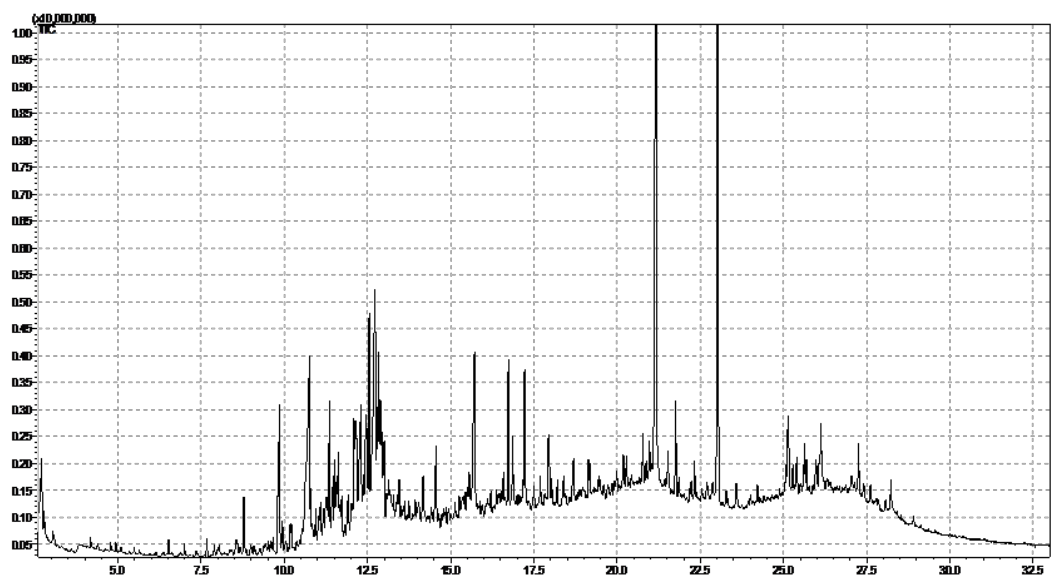

Fig. 3. Chromatogram of the concentrated leachate extract in dichloromethane.

In the case of many peaks, mass spectra and retention indices showed high agreement with mass spectra and retention indexes of several compounds, one peak is assigned in many cases several possible compounds. In most cases these are isomers (e.g. o-, m-, p-), but for some peaks they are different compounds. Also included are peak retention indices, determined on the basis of the analysis of a mixture of aliphatic hydrocarbons (C7-C18) with straight chains and retention indexes of compounds included in the database.

The Figures 4 and 5 show the concentrations of selected compounds.

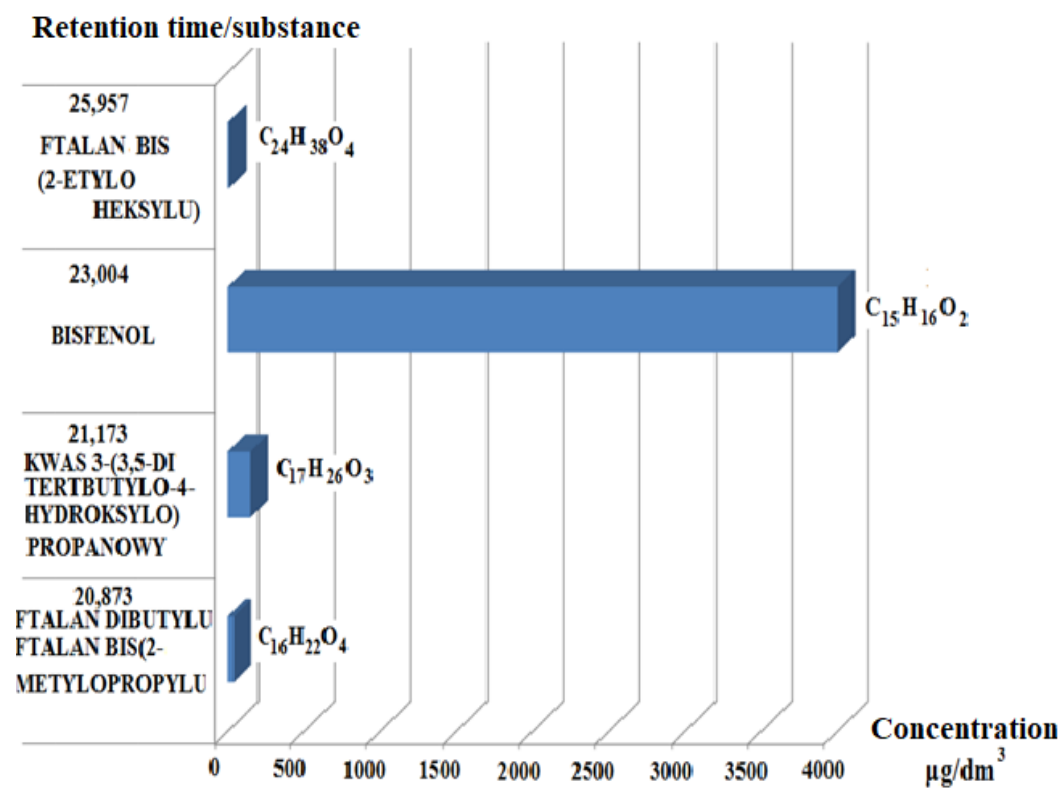

Fig. 4. Concentrations $\left[\mu \mathrm{g} / \mathrm{dm}^{3}\right]$ of chromatographically determined some compounds in the extracts of leachate from the closed landfill of municipal waste Łubna I. 


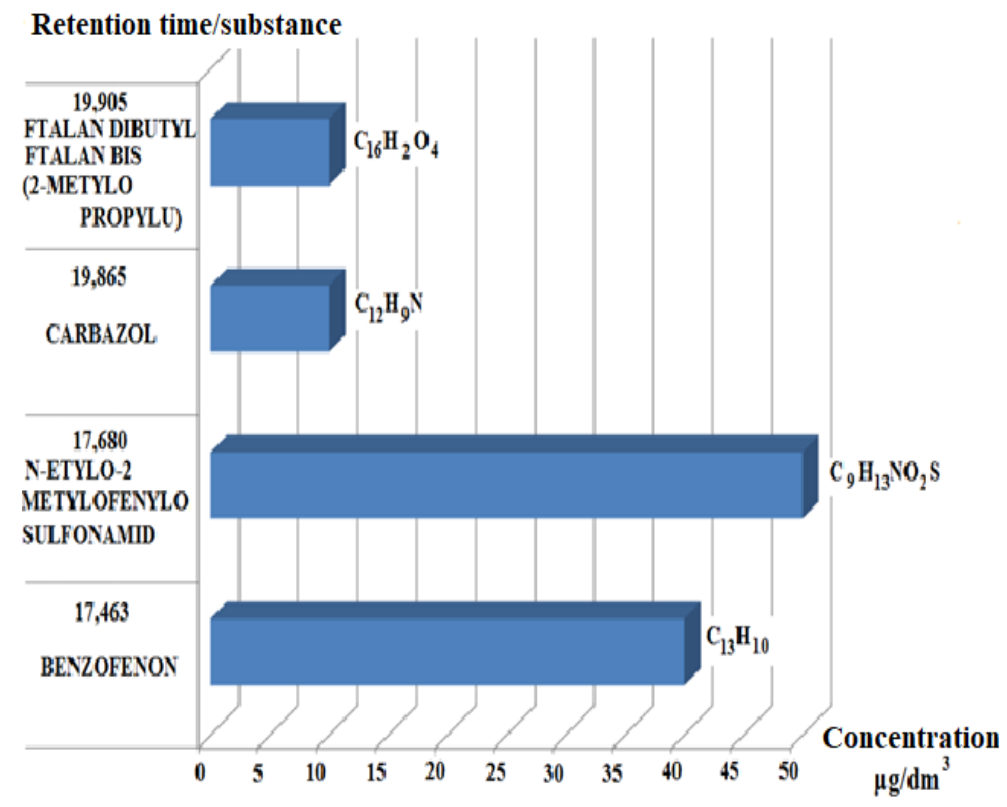

Fig. 5. Concentrations $\left[\mu \mathrm{g} / \mathrm{dm}^{3}\right]$ of chromatographically determined some compounds in the extracts of leachate from the closed landfill of municipal waste Łubna I.

Figures 6 and 7 show the spectra of compounds that in the effluent extracts occurred at the highest concentrations.

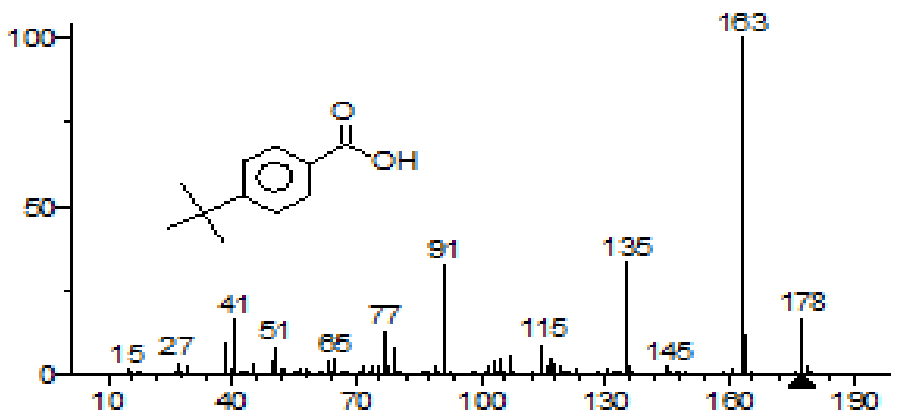

Fig. 6. p-tertbutylbenzoic acid.

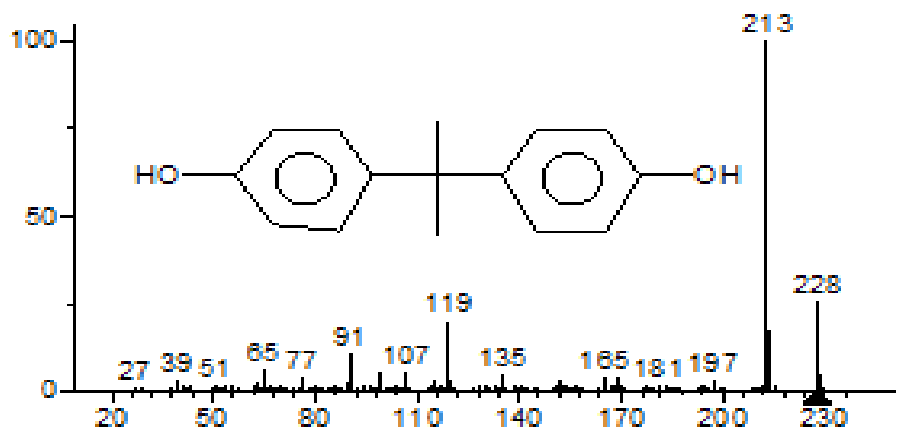

Fig. 7. Bisphenol A. 


\section{Conclusions}

The results of chromatographic tests from both research periods indicate that the concentrations of some compounds present in the leachate extracts have decreased. These compounds include, inter alia, dibutyl phthalate, whose concentration from $350 \mu \mathrm{g} / \mathrm{dm}^{3}$ has dropped to $40 \mu \mathrm{g} / \mathrm{dm}^{3}$. The same applies to toluene. The concentration of this compound decreased to $50 \mu \mathrm{g} / \mathrm{dm}^{3}$ from $270 \mu \mathrm{g} / \mathrm{dm}^{3}$. Research from 2015 did not show the presence of such compounds as: methylbutyric acid, caproic acid. Also 1,3-dimethylbenzene was not detected but other benzene derivatives such as dichlorobenzene, trimethylbenzene, benzoic aldehyde were determined, 1 methyl-3-, 1-methylethylbenzene. Much more other phenol compounds have been determined including: 2-methyloxyphenol about $15 \mu \mathrm{g} / \mathrm{dm}^{3}, 2$ ethylphenol, 3-ethylphenol in amounts of about $30 \mu \mathrm{g} / \mathrm{dm}^{3}, 1$-methylethylphenol about 20 $\mu \mathrm{g} / \mathrm{dm}^{3}$. Particularly noteworthy is the presence of tert-butylbenzoic acid in the concentration of $1000 \mu \mathrm{g} / \mathrm{dm}^{3}$ and bisphenol A, whose concentration was determined at $4000 \mu \mathrm{g} / \mathrm{dm}^{3}$. The high concentration of dibutyl phthalate, determined in the leachate extracts in 2007, could be explained by presence in the waste storage of used plastic parts, usually used for all kinds of household appliances and toys for children. The presence of bisphenol A can also be associated with the increase in the use of polymeric compounds. The production of these materials is related to the use of various types of additives that increase their plasticity, thermostability and hardness. In recent times, the use of bisphenol, which is used, among others, for the production of compact discs, car equipment parts, varnishes that cover metal in cans with food, in objects made of hard plastic such as plates or mugs but unfortunately also for the production of bottles for drinks, including for small children. In the pharmaceutical industry, it is used as an antioxidant. Its global production is about 3.5 million tons per year, and despite the ban on his use, issued by the European Commission in 2011, it is not known how many things containing it went to the Łubna landfill in the last years of operation Bisphenol A can get into groundwater and soils in the event of a leak in the geomembrane installed as a filtration screen. Bisphenol A even in low concentrations may cause disturbances in the biological balance of aquatic ecosystems. The presence of this compound in the environment may cause impairment of the hormonal balance of organisms, increasing the multiplication of fat cells, the development of neoplastic changes and antiandrogenic effects. There are many dangerous compounds in the leachate. Not all of them can be marked. However, measuring the content of organic compounds as COD, it can be concluded that over time, the concentration of some of them decreases, which is associated with physical, chemical and biological changes in the waste deposit. These processes may also lead to the formation of toxic new compounds. Waste that has been imported in the last period before the closure of the landfill, they undergo changes with a delay in relation to previously stored and already decomposed. The substances leached out of them can only be determined after a few years. That is why it is so important to systematically monitor the composition of leachate and the state of the natural environment around the landfill in order to check the tightness of the insulating geomembrane.

\section{References}

1. T. Eggen, M. Moeder, A. Arukwe. Sci. Total Environ. 408 (2010)

2. A. Białowiec. Municipal Overview 10 (2009)

3. A. Polanczyk, Z. Salamonowicz, E3S Web of Conferences 44, 8 (2018)

4. D. Dmochowski, A. Dmochowska and S. Biedugnis, ROS 17 (2015)

5. A. Dmochowska, Statute SGSP (2015) 
6. A. Polanczyk, M. Podyma, L. Stefanczyk, I. Zbicinski, Chem. Eng. Process. 33, 9 (2012)

7. T. Wesierski, M. Majder-Lopatka, R. Matuszkiewicz, R. Porowski, Przem. Chem. 91, 3 (2012)

8. A. Piechota-Polanczyk, A. Goraca, Pharmacol Rep. 64 (2012)

9. A. Piechota, A. Polanczyk, A. Goraca, Pharmacol Rep. 63 (2011)

10. T. Wesierski, M. Majder-Lopatka, W. Wasik, Przem. Chem. 96, 5 (2017)

11. M. Majder-Lopatka, W. Rogula-Kozlowska, W. Wasik, E3S Web of Conferences 44 (2018)

12. A. Piechota, A. Polanczyk, A. Goraca, Pharmacol Rep. 62 (2010)

13. M. Majder-Lopatka and T. Wesierski, E3S Web of Conferences 46 (2018)

14. M. Majder-Lopatka, T. Wesierski, W. Wasik, BITP 42, 8 (2016)

15. A. Piechota-Polanczyk, A. Jozkowicz, Curr. Drug Targets 17 (2016)

16. A. Polanczyk, M. Podgorski, M. Polanczyk, N. Veshkina, I. Zbicinski, L. Stefanczyk, C. Neumayer, Interact. Cardiovasc. Thorac. Surg. (2018)

17. A. Polanczyk, P. Wawrzyniak, I. Zbicinski, Drying Technol. 31, 10 (2013)

18. P. Wawrzyniak, A. Polanczyk, I. Zbicinski, M. Jaskulski, M. Podyma, J. Rabaeva, Drying Technol. 30, 10 (2012)

19. Z. Salamonowicz, R. Makowski, E3S Web of Conferences 44 (2018)

20. P. Wawrzyniak, M. Podyma, I. Zbicinski, Z. Bartczak, A. Polanczyk, J. Rabaeva, Drying Technol. 30, 9 (2012)

21. A. Piechota, A. Goraca, J. Physiol. Pharmacol. 62 (2011)

22. Z. Salamonowicz, M. Kotowski, M. Polka, W. Barnat, Bull. Pol. Ac.: Tech. 63 (2015)

23. W. Jarosz, Z. Salamonowicz, M. Majder-Lopatka, R. Matuszkiewicz, A. Dmochowska, Przem. Chem. 93 (2014)

24. M. Polka, Z. Salamonowicz, M. Wolinski, B. Kukfisz, Procedia Eng. 45 (2012)

25. A. Polanczyk, M. Podyma, L. Stefanczyk, W. Szubert, I. Zbicinski, J. Biomech. 48 (2015)

26. W. Eilenberg, S. Stojkovic, A. Piechota-Polanczyk, C. Kaun, S. Rauscher, M. Groger, M. Klinger, J. Wojta, C. Neumayer, I. Huk, S. Demyanets, Eur. J. Vasc. Endovasc. Surg. 51 (2016)

27. H. Zatorski, M. Salaga, M. Zielinska, A. Piechota-Polanczyk, K. Owczarek, R. Kordek, U. Lewandowska, C. Chen, J. Fichna, Naunyn. Schmiedebergs Arch. Pharmacol. 388 (2015)

28. A. Polanczyk, M. Strzelecki, T. Wozniak, W. Szubert, L. Stefanczyk, Found. Comp. Dec. Sci. 42, 13 (2017)

29. D. Dmochowski, A. Dmochowska, S. Biedugnis, ROS 17 (2015)

30. A. Piechota-Polanczyk, M. Zielinska, D. Piekielny, J. Fichna, Biomed. Pharmacother. 84 (2016)

31. A. Polanczyk, A. Piechota-Polanczyk, C. Domenig, J. Nanobachvili, I. Huk, C. Neumayer, Appl. Sci. 8, 14 (2018)

32. A. Polanczyk, M. Klinger, J. Nonobachvili, I. Huk, C. Neumayer, Appl. Sci. 8, 12 (2018) 
33. A. Polanczy, T. Wozniak, M. Strzelecki, W. Szubert, L. Stefanczyk, Signal Processing SPA 5 (2016)

34. A. Zieminska-Stolarska, A. Polanczyk, I. Zbicinski, J. Hydrol. Hydromech. 644, 8 (2015)

35. Z. Salamonowicz, W. Jarosz, BITP 3 (2012)

36. M. Wlodarczyk, A. Sobolewska-Wlodarczyk, A.I. Cygankiewicz, D. Jacenik, A. Piechota-Polanczyk, K. Stec-Michalska, W.M. Krajewska, J. Fichna, M. WisniewskaJarosinska, J. Gastrointestin. Liver Dis. 26 (2017)

37. M. Salaga, L.V. Blomster, A. Piechota-Polanczyk, M. Zielinska, D. Jacenik, A.I. Cygankiewicz, W.M. Krajewska, J.D. Mikkelsen, J. Fichna, J. Pharmacol. Exp. Ther. 356 (2016)

38. A. Piechota-Polanczyk, S. Demyanets, O. Nykonenko, I. Huk, M. Mittlboeck, C.M. Domenig, C. Neumayer, J. Wojta, J. Nanobachvili, M. Klinger, Eur. J. Vasc. Endovasc. Surg. 45 (2013)

39. A. Polanczyk, A. Piechota-Polanczyk, L. Stefanczyk, PLoS One 12 (2017)

40. A. Polanczyk, M. Podyma, L. Trebinski, J. Chrzastek, I. Zbicinski, L. Stefanczyk, PLoS One 11 (2016)

41. M. Salaga, U. Lewandowska, D. Sosnowska, P.K. Zakrzewski, A.I. Cygankiewicz, A. Piechota-Polanczyk, M. Sobczak, P. Mosinska, C. Chen, W.M. Krajewska, J. Fichna, Naunyn. Schmiedebergs Arch. Pharmacol. 387 (2014)

42. A. Piechota-Polanczyk, M. Wlodarczyk, A. Sobolewska-Wlodarczyk, M. Jonakowski, A. Pilarczyk, K. Stec-Michalska, M. Wisniewska-Jarosinska, J. Fichna, Dig. Dis. Sci. 62 (2017)

43. Z. Salamonowicz, M. Kotowski, M. Polka, W. Barnat, Przem. Chem. 93 (2014)

44. Z. Salamonowicz, M. Wolinski, M. Sobolewski, M. Polka, Przem. Chem. 93 (2014)

45. Z. Salamonowicz, M. Majder-Lopatka, BITP 30 (2013)

46. A. Dmochowska, Wars. Univ. Tech. Pub. (2009)

47. J. Braun, A.E. Kalkbrenner, A.M. Calafat, J.T. Bernert, X. Ye, M. J. Silva, D.B. Barr, S. Sathyanarayana, B. P. Lanphear, Environ. Health Perspect. online publication (2010)

48. D. Li, Z. Zhou,. He. Qing, T. Wu, M. Miao, J. Wang, X. Weng, J.R. Ferber, L.J. Herrinton, Q. Zhu, E. Gao, H. Checkoway, W. Yuan, Human reproduction (Oxford, England) 25, 2 (2010)

49. A. Polanczyk, M. Podgorski, T. Wozniak, L. Stefanczyk, M. Strzelecki, Medicina 54, $15(2018)$

50. D. Zalko, C. Jacques, H. Duplan, S. Bruel, E. Perdu, Chemosphere (2010) 